\title{
SONGS OF PRAISE AND INVOCATION: The Orisha Sacred Songs of Trinidad
}

RICHARD PAUL

THE PURPOSE OF THIS PROIECT IS TO STUDY AND TRANSLATE RECORDED YORUBA CHANTS AND PRAISE SONGS OF TRINIDAD OVER THE PAST 65 YEARS. BECAUSE OF THE HORRIFIC CONDITIONS OF THE TRANS-ATLANTIC SLAVE TRADE, ALMOST ALL ORISHA DEVOTEES HAVE LOST THE MEANING OF THE CHANTS, AND CONSEQUENTLY, THE EMPHASIS IS ON THE RITUALS. I SEEK TO DETERMINE TO WHAT DEGREE THE CHANTS SUNG IN TRINIDAD HAVE REMAINED THE SAME OR CHANGED AND TO WHAT DEGREE THEY HAVE ALL DEPARTED FROM CONTINENTAL YORUBA. ACQUIRING THE TRANSLATIONS ALLOWS DEVOTEES TO ATTAIN A PHILOSOPHICAL UNDERSTANDING OF THE RELIGION, AND IN DOING SO, THIS STUDY AIMS AT RECONSTRUCTING AND UPLIFTING THE ORISHA RELIGION OF TRINIDAD. 
I received an advanced study grant and traveled to Benin West Africa in the summer of 2005 to conduct field research into the Yoruba origins of the Orisha chants of Trinidad. I conducted the first segment of my research in Ketu, an historic Yoruba district located in the eastern part of Benin, 86 miles from Cotonou and 67 miles from Port Novo, the two main cities in the Benin Republic. Ketu has a population of approximately 100,000 inhabitants, 77 percent of whom constitute the Yoruba people, crowded into two of the six communities, namely Ketu (the city) and Idigny/Idahin (a rural town). It was in Idigny that I met with King Oba Thomas Atanda Idowu Arolagbade II and interviewed the chief priests and Orisha devotees.

In Trinidad, the Orisha movement, better known as the Shango religion, which venerates the forces of nature, the Orisha, is the cultural link between Afro-Trinidadians and the Yoruba peoples of West Africa. Streams of Yoruba culture have flowed from the rivers of Africa and into the seas of the Americas. In Trinidad, the essence of Yoruba culture still exists, and Yoruba language has survived in song, primarily because of the vitality of the Shango religion. This collection of Orisha chants translated demonstrates the life experiences of African-Trinidadians, from the African continent, to the Middle Passage, the oppressive slave plantation, and finally the present communities of Trinidad. Unfortunately, most Trinidadians still have a colonized mentality and continue to devalue, ridicule, and demonize the Orisha religious movement. Their contempt for African-based religions does not diminish the joy and fulfillment Orisha devotees gain from their faith.

Over the course of my research experience in the Benin Republic, I was privy to Orisha religious celebrations and observed that the Orisha sacred songs of Trinidadians are reflections of the rhythms and expressions of Yoruba culture. The invigorating drums, the heartbeat of the tradition, and their pulsating rhythms have the power to awaken anyone in their vicinity. The beauty of the Orisha drums is that they elevate our being to higher states of consciousness where, through joy in trance, we dance the dance of our an- cestors. With the exception of some of the sacred songs/chants that I sang, the collection of chants translated in this research included those recorded and sung by Ella Andall, a prominent Trinidadian Orisha devotee, in her most recent CD, Shango Babawa. The translations are not literal per se, but they do convey the ideological, sociological, and contextual meanings. Sung to praise and honor some of the most revered Orisha, in the Orisha spiritual religious traditions, the Oriki praise songs enabled diasporic Africans to reaffirm their Yoruba identity. Their unquestioned trust in their Orisha spiritual traditions enabled diasporic Africans to remember and mentally transport their Orisha to the Americas. Shango, who is the spirit of lightning and thunder, the Orisha of justice of righteousness, the protector of children and the innocent, became the patriarchal head, the bearer and the representation of the Orisha spiritual tradition in Trinidad. Shango, in addition to several Orisha, is the cultural remnant that enslaved Africans brought to the Americas, including the Caribbean island of Trinidad.

Orisha devotees remember the horrors of slavery through the chant of Ara romi o, but they regain hope and assurance in songs like Babawa ye rona ye rona and Shango mu ase fun wa. These lamentations of hope not only reveal their dependency on Shango, but they also show the power andheightened self-esteem they have gained.

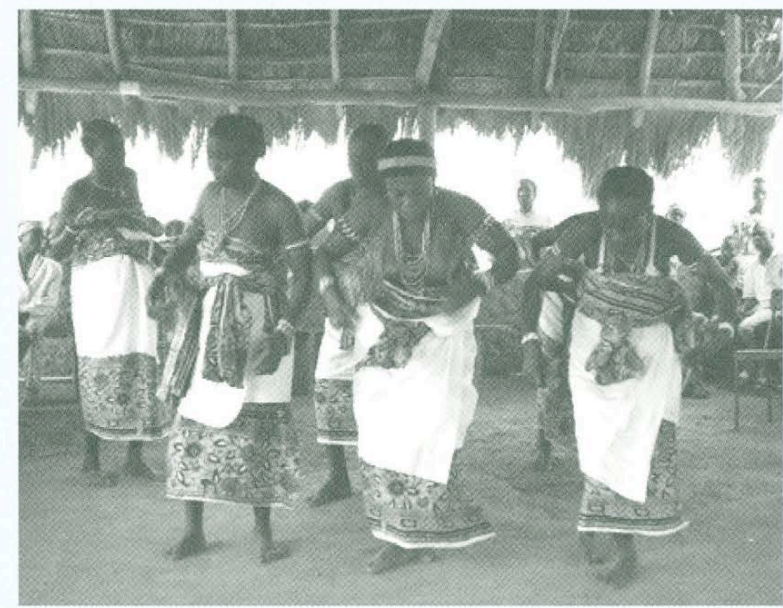


ARA ROMIO

Ara romi o

My body is in pain

Ara romi Shango

SHANGO my body is in pain

Ara romi emitibini

SHANGO I do not want my body to pain

Ara romi Shango

SHANGO my body is in pain

Ojo romi e e

The rain is falling on me [I am experiencing hard times]

Ojo romi Shango

The rain is falling on me [I am experiencing hard times]

\section{BABA YE RONA YE RONA}

Babawa ye rona ye rona

Our father has found a way to be with us

Shango rona

SHANGO has found a way to be with us

Babawa ye rona ye rona

Our father has found a way to be with us

Shango rona

SHANGO has found a way to be with us

\section{SHANGO MU ASE FUN WA}

Shango mu ase fun wa

SHANGO give us the power

\section{Orriwo}

You have the power

Shango fun wa

SHANGO has given us the power

Orriwo

You have the power

Mu ase fun wa

Give us the power

Orriwo

You have the power

Babawa fun wa

Our father has given us the power
In times of hardships, many questioned their faith and subjected themselves to despair as seen in Ka rele. However, some of the devotees' unquestionable trust in their religion corrects those doubts when they reminded others of Shango's vitality, as observed in Emi ni ape Shango l'ojo.

KA RELE

Ka rele

Let us go home

Ka rele o

Let us go home!

Ka rele ojo moni owo

Let us go home, the rain has no regards for anyone

Ojo baa de

Let the rain come!

Onian wa, bi ojo baa de onian wa

People come, even if there is rain, people come

EMI NI APE SHANGO L'OJO

Emi ni ape Shango l'ojo

I say that they [devotees] call SHANCO during the rain Thard times]

Shango de omi lala l'ojo

SHANGO has come [even if] there is plenty water [hard times] Omi lala l'ojo

There is plenty water [hard times]

Orisha devotees have no qualms about portraying or about celebrating Shango's aggressiveness, his omnipotence and his unscathed vengeance as the fierce protector in songs like Shango oloro.

\section{SHANGO OLORO}

Shango oloro

SHANGO is deadly

Shango olo oloro

SHANCO Owns snake venom [SHANCO is lethal]

Shango o

Hail SHANGO!

Shango oloro

SHANGO is deadly 
Shango Babawa is a typical song of invocation and Fere ku fero yero and Emi l'awa ko pemi la fise emi l'awa are traditional praise songs.

SHANGO BABAWA

Shango Babawa

Our father SHANGO

Shango Alado karele

SHANGO, the wearer of powerful amulets, let us go home and pay homage

Shango Babawa Olododo

Our father SHANCO, the most powerful

Kabiese O!

[Prostrating gesture/greeting of respect]

FERE KU FERE YERO

Fere ku fero yero

You [SHANCO] are worthy to be praised gracefully

La finsi Babawa

Our dear father

Fere ku fere Shango

SHANGO is worthy to be praised gracefully

La finsi Babawa

Our dear father

EMI L'AWA KO PEMI LA FISE EMI L'AWA

Emi l'awa ko pemi la fise emi l'awa

Whenever you [SHANGO] call me, I will come and serve you Shango ko pemi la fise

SHANGO I will come and serve you

Emi l'awa ko pemi la fise emi l'awa

Whenever you [SHANGO] call me, I will come and serve you Shango ko pemi la fise

SHANGO I will come and serve you
Most Shango ceremonies dismiss Shango and bring closure with Tete ma lo Shango and/or Eru dele O.

TETE MA LO SHANGO

Tete ma lo Shango

Depart quickly SHANGO

Tete ma lo

Depart quickly

Shango o! Tete ma lo

Hail SHANGO! [Now] depart quickly

Tete ma lo Baba

Depart quickly father

Tete ma lo

Depart quickly

Shango o! Tete ma lo

Hail SHANGO! (Now) depart quickly

ERU DELE

Eru dele O

Your servant has come to your shrine

Eru de

Your devotee has arrived

Mo juba

I pay homage

Mo lo

I leave

Eru de

Your devotee has come

Mo juba

I pay homage

Mo lo o!

[And] I leave

\section{"Emi l'awa ko pemi la fise emi l'awa Whenever you [SHANGO] call me, I will come and serve you"}

